\title{
トリエチルホスファイトと $\mathbf{N}-$ ブロムアセ トアミドの反応
}

\section{中里敏*桶 口勝 彦*}

The Reaction between Triethyl Phosphite and N-bromoacetamide.

\section{Satoshi NaKasato* and Katsuhiko Higuchi*}

\begin{abstract}
An attempt to prepare $\mathrm{N}$-acetylphosphoroamidate by the reaction of triethyl phosphite with $\mathrm{N}$-bromoacetamide in ether was unsuccessful, and the reaction did not produce acetonitrile. In this reaction it was found that diacetamide hydrobromide and triethyl phosphate were formed neanly quantitatively. It seemed reasonable to assume that the phosphonium intermediate in this reaction is extremely unstable against moisture. The infrared and mass spectra of diacetamide hydrobromide were also determined.
\end{abstract}

\section{I. 概 要}

トリエチルホスファイトと N-ブロムアセトアミドの 反応により N-アセチルホスホロアミデート誘導体を得 ようとしたが目的物は得られなかった。またアセトニト リルも生成しなかった。

この反応ではジアセトアミドハイドロブロミドとトリ エチルホスフェートがほとんど定量的に得られることを 知った。この原因は恐らく反応で生成するホスホニウム 中間体が水分に対して不安定なためと思われる。ジアセ トアミドハイドロブロミドの IR およびマススペクトル を示した。

\section{II. 緒言}

N-P 結合をもつ有機リン化合物については非常に多 くの研究がなされているが，その多くはアミンを原料と して合成したもので, アミドから出発した誘導体の報告 杜少ない。・

酸アミドと五塩化リンの反応で N-アシルホスホロア

* 工業技術院東京工業試験所

* Government Chemical Industrial Research Institute, Tokyo

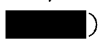

ミド酸塩化物を得た報告1) はあるが，酸アミドは芳香族 酸アミドあるいは八ロゲン置換アルキル鎖をもつ脂肪族 酸アミドに限られ，それら以外加ら相当するニトリル しか生成しない。

三価のリン化合物による $\mathrm{N}$-ハロアミドの求核置換と しては，N-ハロアミドとホスフィンの反応でニトリル を生ずること尕が知られて拈り，また一方 N-ブロムコ ハク酸イミドとトリブチルホスファイトの反応では P-N 結合をもつ N-(ジブチルホスホロ)サクシンイミドが生 成した報告3)がある。

著者らは N-ブロムアセトアミドとトリエチルホスフ アイトの反応から N-アセチルホスホロアミデートが得 られないかと考え実験をおこなったが，目的とする Nアセチルホスホロアミデートは得られず，またニトリル も生成せず，ジアセトアミドハイドロブロミドとトリエ チルホスフェートがほとんど定量的に得られることを知 った。

\section{III. 実 験}

1. 試薬 N-ブロムアセトアミドはアセトアミド から Oliveto ら ${ }^{4}$ の方法により合成した。収率，48\%， 純度 $98.5 \%, \mathrm{mp} 103 \sim 106^{\circ} \mathrm{C}$ 。 
トリエチルホスファイトは試薬 1 級を蒸留して bp 44 $\sim 45^{\circ} \mathrm{C} / 11 \mathrm{mmHg}$ の留分を使用した。

2. 反応 N-ブロムアセトアミド $34.5 \mathrm{~g}$ (0.25 モ ル) をエーテル $200 \mathrm{ml}$ に懸濁させ，これにトリエチル ホスファイト $41.5 \mathrm{~g}$ (0.25 モル) をエーテル $200 \mathrm{ml}$ に溶かした溶液を徐々に適下する。反応液は十分かきま ぜながら $10^{\circ} \mathrm{C}$ 以下に保つように冷却した。ホスファイ トを滴下すると激しく反応し臭化水素と思われる白煙を 生じた。滴下とともに反応液は赤, 黄, 無色と順次変化 し，黄色が淡くなる頃白色の沈殿を生成した。反応終了 後, 沈殿をロ別し，口液からエーテルを留去すると淡黄 色液体を得た。この沈殿部と液状部について検討した。

3. 測定 IR スペクトルは日立 EPI-S 赤外分光器 を用い，固体試料は $\mathrm{KBr}$ 錠剤法，液体試料は薄膜法で 求めた。マススペクトルは C.E.C.-110B 型マススペク トロメーターを用い, $80^{\circ} \mathrm{C}, 70 \mathrm{eV}, 100 \mu \mathrm{A}$ で測定し た。

\section{IV. 結果および考察}

1. 沈殿部口過した沈殿をアセトンから再結晶し て白色針状結晶を得た。アセトンーヘキサンから再結晶 すると板状結晶となる。この結晶は水，アルコールに易 溶，アセトンには熱時可溶，その他の有機溶剤には不溶 で，わうが吸湿性を示した。アセトン再結晶をくり返 した結晶は $125 \sim 130^{\circ} \mathrm{C}$ で昇華，封管中では $145 \sim 146^{\circ} \mathrm{C}$ で融解した。

重水溶液で NMR スペクトルを求めるとT值 7.45 ppm にメチル基によるシグナルのみを示し，メチレン 基は示さない。したがってこの結晶のアルキル鎖として はメチル基だけでホスファイトからのエチル基は含まれ ていないと思われる。

IR スペクトルを図 1 に示した。 $3300 \mathrm{~cm}^{-1}, 3200 \mathrm{~cm}^{-1}$

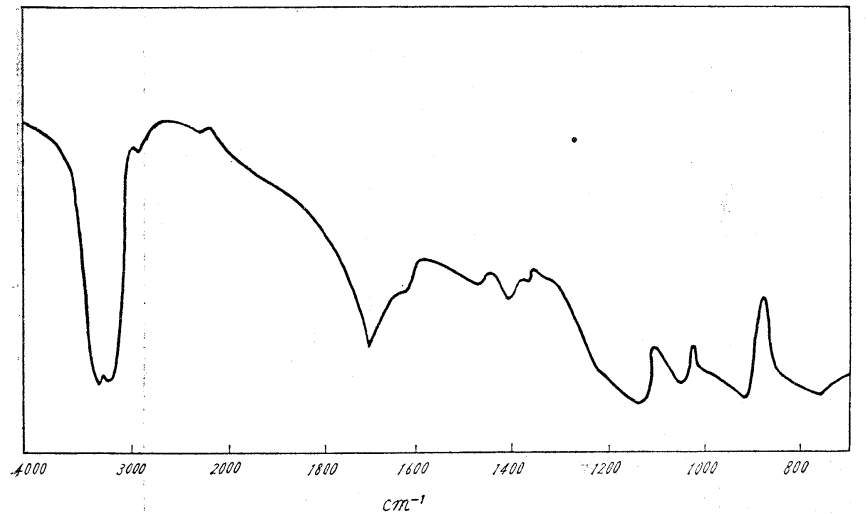

図 1 結晶(ジアセトアミドハイドロブロミド)の IR スペクトル
に NH 対称, 非対称伸縮による 2 本の吸収, $1690 \mathrm{~cm}^{-1}$ にアミドIの吸収を示し- $\mathrm{CONH}_{2}$ の存在が考えられ る。

結晶のマススペクトルをアセトアミドと比較して 図 2 に示した。 $\mathrm{HBr}$ フラグメントによる $\mathrm{m} / \mathrm{e} 80,82$ の 2 本 のピークが強いことは $\mathrm{Br}$ は $\mathrm{C}-\mathrm{Br}$ でなく $\mathrm{HBr}$ として 存在すると思われる。親イオンのピークは現れず，その 他の質量数のピークはアセトアミドのピークと極めてよ く一致している。
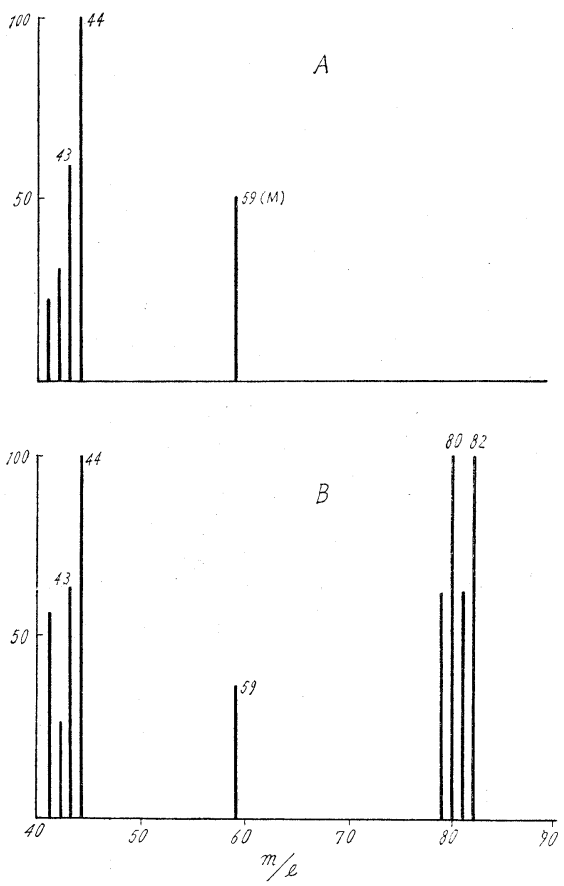

図 2 マススペクトル

A :アセトアミト

$\mathrm{B} ：$ 結晶（ジアセトアミドハイドロブロミド）

分析值 C $24.13 \%$, H 5.22\%, N $13.79 \%$ $\mathrm{Br} 40.84 \%$

$\mathrm{C}_{4} \mathrm{H}_{11} \mathrm{O}_{2} \mathrm{~N}_{2} \mathrm{Br}$ としての

計算值 C $24.13 \%, \mathrm{H} 5.58 \%, \mathrm{~N} 14.07 \%$ Br $40.14 \%$

中和当量 測定值 199.20

$\left(\mathrm{CH}_{3} \mathrm{CONH}_{2}\right)_{2} \mathrm{HBr}$ としての 計算值 199.07

以上の結果からこの結晶はジアセトアミド八 イドロブロミド $\left(\mathrm{CH}_{3} \mathrm{CONH}_{2}\right)_{2} \mathrm{HBr}$ であるこ とを確認した。

アセトアミドとハロゲン化水素の $2: 1$ 分子 付加化合物としてはジアセトアミドハイドロク 
ロリドの報告5) がある。ハイドロブロミドについては Mitts ら ${ }^{6)}$ がアセトブロモグルコーズとアセトアミドの 反応で得たと報告しているが，昇華温度と融点を示した だけで，その他の性質については記載されていない。

2. 液状部 水汇可溶で $\mathrm{pH} 5, \mathrm{pH} 7$ に中和点を示

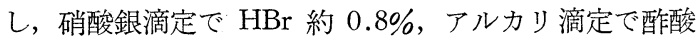
約 $2 \%$ が含まれていることを知ったが，恐らく副反応生 成物と思われる。

酸性部を除去した中性部の IR スペクトルはトリエチ ルホスフェートと一致した。

分析值 P $17.24 \%$

$\left(\mathrm{C}_{2} \mathrm{H}_{5} \mathrm{O}\right)_{3} \mathrm{PO}$ としての

計算值 P $17.04 \%$

N-ブロムアセトアミドとトリアルキルホスファイト を種々の条件で反応させた結果を表 1 に示した。エー テル中， $10^{\circ} \mathrm{C} ， 1$ モル/1モルの反応で $1 / 2$ モルのジアセ トアミドハイドロブロミドと 1 モルのトリエチルホスフ エートがほぼ定量的に生成することを知った。四塩化炭 素, ベンゼン中の反応生成物の組成については検討しな かった。

N-ブロムアセトアミドとトリェチル ホスファイトの 反応では中間に生成するホスホニウム塩がきわめて不安 定で，水により $\mathrm{HBr}$ が離脱しやすくジアセトアミド八
表 1 N-ブロムアセトアミドとトリアルキルホスフ フイトの反応

\begin{tabular}{|c|c|c|c|c|}
\hline \multirow{2}{*}{$\underset{\text { モル }}{\mathrm{CONHBr}_{3-}}$} & \multirow{2}{*}{$\begin{array}{l}(\mathrm{RO})_{3} \mathrm{P} \\
\text { モル }(\mathrm{R})\end{array}$} & \multirow{2}{*}{ 溶凨, 温度 } & \multicolumn{2}{|c|}{ 生 成 物 } \\
\hline & & & $\begin{array}{l}\left(\mathrm{CH}_{3} \mathrm{CO}\right. \\
\left.\left.\mathrm{NH}_{2}\right)_{2} \mathrm{HBr}^{\mathrm{a}}\right)\end{array}$ & $(\mathrm{RO})_{3} \mathrm{PO}^{\mathrm{b})}$ \\
\hline 0.14 & $0.14(\mathrm{Et})$ & エーテル, 10 & 0.06 モル & 0.13 モル \\
\hline 0.26 & $0.26(" \prime)$ & , " & 0.10 & 0.24 \\
\hline 0.07 & $0.07(" 1)$ &, 20 & 0.02 & 0.02 \\
\hline 0.03 & $0.03(\mathrm{Bu})$ &, 10 & 0.005 & - \\
\hline 0.04 & $0.04(\mathrm{Et})$ & 四塩化炭素, " & 0.01 & 0.03 \\
\hline " & $"(")$ & ベンゼン," & $"$ & " \\
\hline
\end{tabular}

a) 粗沈殿として。

b) 粗液状部として。

イドロブロミドを生成するものと思われる。

付記 本研究は昭和 44 年 11 月 7 日第 8 回油化学討論 会で発表した。

\section{文献}

1) J.V. Braun, W. Rudolph, Ber. 671762 (1934)

2) S. Trippett, D.M. Walker, J. Chem. Soc. 1960 2976

3) A.K. Tsolis, W.E. McEwen, C.A. Vander Werf Tetrahedron Letters 19643217

4) E.P. Oliveto, C. Gerold "Organic Syntheses" Vol. 31, 17 (1951)

5) H. Stephen, J. Chem. Soc. 1931672

6) E. Mitts, R.M. Hixon, J. Am. Chem. Soc. 66 483 (1944)

\section{有機合成化学協会誌 バックナンバー在庫表}

（昭和 45 年 10 月現在）

下記バックナンバーが在庫しておりますから，ご入用の方は巻・号明記の上代金・送料 を添えてお申し込み下さい。な第 3 巻〜第18巻のバックナンバーも多少在庫致しており ますからご照会下さい。

\begin{tabular}{|c|c|c|c|c|c|c|c|c|c|c|c|c|c|c|c|}
\hline Vol. & 19 (昭柇 & 36. & '61) & No. & & & & & 5 & 6 & & & 10 & & \\
\hline " & $20(" 1$ & 37. & '62) & $"$ & & 2 & & 4 & 5 & 6 & & 9 & 10 & 11 & 12 記 \\
\hline " & 21 (") & 38. & '63) & " & 1 & & & & & 6 & 7 & 9 & 10 & & 12 \\
\hline " & $22($ " & 39. & '64) & $" 1$ & & 2 & & 4 & & & 7 & & 10 & 11 & 12 \\
\hline " & $23(")$ & 40. & '65) & $" \prime$ & & & & & & 6 & & & 10 & & \\
\hline " & $24(")$ & 41. & '66) & $" \prime$ & & & & & & & & & & 11 & $12^{*}$ \\
\hline " & $25(\mathrm{\prime \prime}$ & 42. & '67) & " & & & & & & & 7 & 9 & & & \\
\hline " & $26(")$ & 43. & '68) & "I & & & & & & & & & 10 & & \\
\hline " & 27 ( I" & 44. & '69) & " & & 2 & 3 & 4 & 5 & 6 & 7 & 9 & 10 & 11 & \\
\hline " & $28(")$ & 45. & '70) & $"$ & & & & & & & & 9 & 10 & & \\
\hline
\end{tabular}

頒価：1冊 400 円・送料 18 円

記 : 20 周年記念号 400 円・送料 24 円 * : 特集号 450 円・" 24 月

（注）バックナンバーの頒価は，すべて 400 円です。 